\title{
Kidney Regeneration: Common Themes From the Embryo to the Adult
}

\author{
M. Cecilia Cirio ${ }^{1}$, Eric D. de Groh ${ }^{1}$, Mark P. de Caestecker ${ }^{2}$, Alan J. Davidson ${ }^{3}$, and Neil A. \\ Hukriede $^{1, *}$
}

${ }^{1}$ Department of Developmental Biology, University of Pittsburgh, Pittsburgh, PA, United States of America ${ }^{2}$ Department of Medicine, Division of Nephrology, Vanderbilt University Medical Center, Nashville, TN, United States of America ${ }^{3}$ Department of Molecular Medicine and Pathology, School of Medical Sciences, University of Auckland, Auckland, New Zealand

\begin{abstract}
The vertebrate kidney has an inherent ability to regenerate following acute damage. Successful regeneration of the injured kidney requires the rapid replacement of damaged tubular epithelial cells and reconstitution of normal tubular function. Identifying the cells that participate in the regeneration process as well as the molecular mechanisms involved may reveal therapeutic targets for the treatment of kidney disease. Renal regeneration is associated with the expression of genetic pathways that are necessary for kidney organogenesis, suggesting that the regenerating tubular epithelium may be 'reprogrammed' to a less-differentiated, progenitor state. This review will highlight data from various vertebrate models supporting the hypothesis that nephrogenic genes are reactivated as part of the process of kidney regeneration following acute kidney injury (AKI). Emphasis will be placed on the reactivation of developmental pathways and how our understanding of the resulting regeneration process may be enhanced by lessons learned in the embryonic kidney.
\end{abstract}

\section{Keywords}

organogenesis; regeneration; acute kidney injury

\section{Introduction}

The paradigm that regenerative signaling events initiated in adult organs recapitulate the molecular pathways activated during embryonic development has been a long-held hypothesis $[1,2]$. The rationale behind this hypothesis may not be immediately apparent, since the initial processes necessary for establishing organ fields during embryogenesis and those that compensate for tissue loss during regeneration are quite dissimilar. Establishing a developing organ field occurs via inductive signals and morphogenetic movements, while regeneration typically initiates with damage and cell death [3]. However, once the first regenerative steps have occurred, the next stages, which start with progenitor cell recruitment or establishment followed by proliferation and differentiation, rely on signaling cascades that also play a role in organ formation during development.

*Correspondence: Dr. Neil A. Hukriede, Department of Developmental Biology, University of Pittsburgh, $35015^{\text {th }}$ Ave., 5061 BST3, Pittsburgh, PA 15213. Phone: 412-648-9918; hukriede@ pitt.edu. 
The kidney is a key homeostatic regulator of electrolytes and water, and uses blood filtration as a means of waste removal. Despite performing these essential functions, the mammalian kidney possesses a limited regenerative potential. While localized lesions in the tubular epithelium of nephrons (the basic filtering units) can be repaired, entire nephrons cannot, resulting in a permanent deficit [4-6]. In contrast, the adult zebrafish kidney not only has the ability to repair injured tubular epithelium, but also the potential to generate nephrons $d e$ novo following severe injury through a process termed neo-nephrogenesis [7]. Although there is wide disparity in the renal regenerative potential found between different vertebrates, the reactivation of multiple embryonic signaling pathways during regeneration supports the hypothesis that these pathways play similar roles in both embryonic kidney formation and adult replacement of renal tissue [8-10]. In this review we will highlight the common features of kidney organogenesis and regeneration, as revealed from studies of several well-known molecular pathways (Figure 1).

\section{Vertebrate Kidney Organogenesis}

In adult human kidneys there are at least twenty-six different cell types [11]. However, all renal cells and their descendants arise during embryonic development from the intermediate mesoderm (IM), located between the paraxial mesoderm (PM) and lateral-plate mesoderm (LPM) [12]. Signals from these juxtaposed tissues define the boundaries of the emerging IM and induce the expression of the early-acting renal transcription factor genes Pax2, Pax8, Lhxl, and Osrl [13-15].

Vertebrates form up to three different types of kidney, with increasing complexity. In general, the nephrons of all kidney types are composed of a blood filter (glomerulus) and a renal tubule that is subdivided into proximal and distal segments. The first kidney type, the pronephros, forms in the upper trunk of the embryo and serves as the functional larval kidney in fish, amphibians and some reptiles [16, 17]. Because they contain only rudimentary nephric structures, the pronephroi of certain reptiles, birds, and mammals lack excretory capability [16]. However, regardless of pronephric activity, development of the subsequent kidney types is dependent on the initial formation of the pronephric (aka nephric) duct [15]. The next embryonic kidney to arise, the mesonephros, constitutes the adult kidney in fish and amphibians, and the functional fetal kidney of mammals. Mesonephric development begins when IM-derived mesenchymal cells near the nephric duct condense (pre-tubular aggregates) and epithelialize to form renal vesicles, the first step in nephron formation. Renal vesicles transition into S-shaped bodies and then finally into mesonephric nephrons [12]. Development of the final form of the kidney, the metanephros, which is the functional adult kidney in reptiles, birds, and mammals, begins with a posterior outgrowth of the nephric duct near the hind limb, called the ureteric bud [12]. Signals from the ureteric bud initiate the condensation of the metanephric mesenchyme into nephrons (via pre-tubular aggregate, renal vesicle, and S-shaped body transitions), while the metanephric mesenchyme reciprocally induces growth and branching of the ureteric bud. This process continues until the emergence of the adult kidney, the metanephros, which can contain approximately 1,000,000 nephrons per kidney in humans, along with a highly branched collecting duct system [12].

\section{Vertebrate Kidney Regeneration}

Regenerative responses show distinct patterns in different organs, and are usually related to the organs inherent rates of cellular turnover. Highly proliferative organs, such as the blood lineages, intestine, and skin contain a resident stem cell population serving as the source of replacement cells $[18,19]$. In contrast, the mammalian kidney exhibits a low basal cellular turnover and does not appear to contain a well-defined stem cell population. However, 
kidney damage can trigger varying degrees of regenerative responses depending on the organism and the extent of the damage [7].

Acute kidney injury (AKI) is defined as a rapid loss of kidney function as evidenced in mammals by elevated serum creatinine and/or blood urea nitrogen levels or a severe decrease in urinary output. It accounts for approximately $7 \%$ of all inpatient hospital admissions and is most commonly caused by ischemic injury, exposure to nephrotoxic agents and/or sepsis [20]. Renal replacement is the only approved therapy for the majority of the patients with severe AKI and there are no established treatments that have been proven to prevent renal injury or accelerate recovery following AKI.

At the cellular level, AKI-mediated damage results in depolarization of renal tubular cells and subsequent loss of function and cell death through apoptosis and necrosis [21-23]. The proximal straight tubule ( $\mathrm{S} 3$ segment) is highly susceptible to ischemia and toxic insult leading to AKI [24]. Early cellular changes observed in the proximal straight tubule are loss of cell polarity and the brush border, disruption of tight and adherent junctions and redistribution of the $\mathrm{Na}+/ \mathrm{K}+\mathrm{ATPase}$ and integrins to the apical plasma membrane $[25,26]$.

Both the zebrafish pronephros (larval kidney) and mesonephros (adult kidney) have been successfully used as models to study AKI. Injection of the nephrotoxic agents, gentamicin and cisplatin into the circulatory system of zebrafish larvae, induces a decline of renal function and histological changes characteristic of mammalian AKI models [27-29] In the adult zebrafish mesonephros, following gentamicin-mediated AKI, and it was found that new nephrons formed after injury and were found to originate from cellular aggregates of potentially self-renewing progenitor cells in a process of regenerative neo-nephrogenesis [30].

In mammals, the renal epithelium has the capacity to self renew by symmetric division of differentiated cells that are indistinguishable from their progeny $[6,31]$. However, the mechanism by which renal tubular epithelium regenerates following injury remains unclear. A large number of studies have used rodent models of ischemia-reperfusion, where epithelial cell death by necrosis is largely restricted to the $\mathrm{S} 3$ segment of the proximal tubule and occurs within the first 12-24 hours of injury. This is associated with renal tubular epithelial cell (RTEC) loss, denudation of areas of basement membrane, and loss of cell-cell junctions between surviving RTECs, resulting in flattened cellular morphology and the expression of mesenchymal markers such as vimentin [32-34]. Depending on the severity of the insult, regeneration of injured RTECs occurs over the next 1-7 days, as rapidly-dividing vimentin-positive cells undergo a mesenchymal-to-epithelial transition and eventually form functional, polarized epithelia.

Lineage tracing studies suggest that the bulk of regenerating RTECs are derived from intrinsic renal epithelium, and not through migration and differentiation of extrarenal or intrarenal stem cells [35]. The majority of these proliferating cells appear to be derived from slow-cycling, BrdU-retaining tubular epithelial cells, which are scattered throughout the proximal tubule and are indistinguishable from fully differentiated tubular epithelial cells prior to injury [36]. These findings are consistent with observations made in regenerating pancreas, liver and bronchial epithelial injury models [37-39], and suggests that the bulk of regeneration in these low-turnover epithelial organs occurs by dedifferentiation and proliferation of endogenous epithelial cells. Nonetheless, it is still possible that exist discrete populations of renal stem cells in the adult kidney, which are reactivated following certain types of injury. One such potential population has been found in the epithelial capsule that surrounds the glomerulus. A subset of these cells that co-express the stem cell markers, CD24 and CD133 are able to prevent renal damage and accelerate recovery time when 
injected into mice with AKI [40]. The existence of adult renal stem cells in mammals and their role in kidney regeneration remains controversial and more lineage-tracing experiments are needed to resolve this issue [41-44].

In addition to the re-expression of mesenchymal markers, regenerating RTECs express genetic markers normally associated with pre-tubular aggregates and renal vesicles, including Pax2, Wnt4, Lhxl and components of the Notch and BMP signaling pathways [10, 45-47]. These genes are expressed within the first 24 hours following injury and cease to be transcribed once the cells undergo epithelial differentiation. The mechanism regulating reactivation of embryonic gene expression following AKI is unknown. In the following section, we will highlight several well-characterized pathways that are required for kidney organogenesis and are reactivated during regeneration, but by no means is this a complete list of conserved pathways (Table 1). While there is a lot of functional data for these pathways during kidney organogenesis,, most of the reported regeneration data is based on reactivation of expression of conserved orthologs gene loci and functional studies are currently limited.

\section{Conserved Pathways in Kidney Development and Regeneration}

\section{Retinoic acid signaling}

Retinoic acid (RA) is the active derivative of vitamin A, and is necessary for proper growth and development of the vertebrate embryo, including the kidney [48]. RA synthesis involves two oxidation steps: First, vitamin A is converted to retinaldehyde by alcohol dehydrogenases (ADHs), then retinaldehyde dehydrogenases (RALDH or ALDH) process the retinaldehyde to RA [49]. Degradation of RA is primarily mediated by the Cytochrome p450 enzymes (Cyp26 a1, b1 and c1) [50]. RA diffuses into the cell and binds to retinoic acid receptors (RARs $a, \beta$, and $\gamma$ ) in the nucleus, which heterodimerize with the retinoid $X$ receptors (RXRs $\alpha, \beta$, and $\gamma$ ) and recruit transcriptional co-activators on target genes [51, $52]$.

RA has been shown by several groups to be involved in the early events of kidney specification and induction of pronephric cell fates [53-59]. In vitro studies of Xenopus laevis ectoderm explants treated with activin A and RA resulted in induction of pronephric fates and implicated RA as a regulator of renal development [55]. RA has been shown to be one of the earliest signals in pronephros formation [53]. Defective RA signaling impairs pronephros development, prevents expression of the early pronephric genes Lhxl and Pax8, and reduces gene expression in proximal regions (nephrostomes and proximal tubule), suggesting that RA signaling regulates pronephric development by directly affecting pronephric progenitors during gastrulation [53]. Further, raldh2-deficient zebrafish embryos or those treated with compounds that block RA signaling have defects in pronephric formation characterized by fewer podocytes, shorter or absent proximal tubule segments and expanded distal tubules [58]. A gradient of RA is postulated to occur along the early field of nephron progenitors thereby determining whether a proximal (high RA) or distal (low or no RA) tubule fate is adopted [60].

Pronephric duct development is impaired in $R$ aldh $2^{-/-}$mice suggesting that the role of RA signaling is evolutionary conserved in vertebrates during the early steps of kidney formation [53]. During metanephric development, reduced RA availability leads to multiple abnormalities. Depending on the extent of RA deficiency, the associated phenotypes include hydronephrosis, renal hypoplasia and horseshoe kidney [61-63]. These renal abnormalities are recapitulated in mice carrying genetic alterations in retinoid receptors [51, 52, 64]. In double mutant mice RAR $\alpha \beta \gamma$, kidneys show no nephrogenic zone at 18.5 -dpc. The ureteric bud reaches the metanephric mesenchyme but branching morphogenesis is impair 
suggesting the requirement of both retinoic acid receptors in this process [64]. The observation that RA controls branching morphogenesis by regulating Ret expression in the ureteric bud and the observed phenotype in RARaß2 double mutant mice indicated that the renal malformation in these mice results from down-regulation of Ret signaling in the ureteric bud, ultimately causing impaired branching morphogenesis [65].

Retinoids have also been implicated in the process of repair and regeneration of the mammalian central nervous system [66-70], mammalian lungs [71-73], and zebrafish heart $[74,75]$. In the kidney, retinoids have not been shown to augment the regenerative response but rather to ameliorate renal injury. In a nephritic rat model of glomerular damage induced by targeting mesangial cells, RA effectively limits damage, inducing a recovery in renal function and preserving glomerular structure [76]. Increased Raldh2 expression in rats with podocyte damage suggests that endogenous RA production could play a role in the repair process [77]. Interestingly, administration of RA to these rats prevents puromycin aminonucleoside-induced proteinuria indicating the importance of RA in the repair process of the injured podocytes. In a rat model of potassium dichromate induced AKI, pretreatment with RA prevents a decrease in glomerular function, reduces oxidative damage and accelerates recovery. This effect has been attributed to the prevention of cellular damage induced by oxidative stress and maintenance of epithelial integrity in the proximal tubule [78]. Together, these reports indicate a potential RA amelioration of renal damage although further studies are needed to elucidate the molecular mechanism involved.

\section{Early transcription factors}

The paired-box (Pax) gene family encodes transcription factors characterized by the presence of a paired domain that confers sequence-specific binding to DNA [79]. Two members of the family, Pax2 and Pax8, are expressed in the developing mouse kidney [8082]. In Pax2-null mice the nephric duct forms but does not fully migrate posteriorly and then degenerates. In addition, only a few mesonephric structures arise and there is a lack of metanephric kidney formation in Pax 2 mutants. Pax8-null mice exhibit no kidney defects

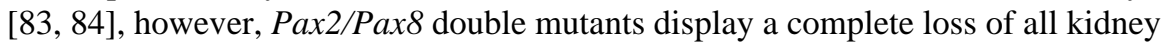
structures [85]. Zebrafish embryos deficient in the homolog of Pax2, pax2a, and pax8 lack pronephric tubules, although glomerular morphogenesis remains relatively unaffected [86].

The lack of metanephric development in Pax2 null mouse embryos suggests that Pax2 target genes may play a role in ureteric bud budding [84]. In support of this, Pax 2 is necessary for the expression of $G d n f$, encoding an important secreted inducer of ureteric bud outgrowth $[87,88]$, in the metanephric mesenchyme [89]. Current evidence suggests that Pax 2 forms a complex with the co-regulators Hox 11 and Eya1 to directly control the expression of $G d n f$ in the metanephric mesenchyme [90]. Exogenous replacement of Gdnf in Pax2 null kidney organ cultures fails to restore ureteric bud formation [89] indicating that $P a x 2$ also regulates the response of the nephric duct to Gdnf [89]. Consistent with this, Pax2 directly binds to the Gdnf receptor (Ret) promoter and expression of Ret is lost in Pax2 null embryos [91].

Pax8 also contributes to collecting duct branching as the metanephric kidneys of doubleheterozygous Pax $2 / 8$ embryos exhibit decreased expression of Wnt 11 , a downstream target of Gdnf-Ret signaling [92]. Interestingly in these animals, the expression levels of $G d n f$ and Ret appear unaffected. While there are clearly many molecular details yet to be resolved, these results indicate that $\operatorname{Pax} 2$ and $\operatorname{Pax} 8$ have important roles both up- and down-stream of the GDNF-Ret pathway to regulate collecting duct branching.

Of the two members of the Pax family expressed during kidney organogenesis, Pax 2 has been studied in the greatest detail during kidney regeneration. In the metanephric kidney, Pax2 expression is down-regulated during epithelial differentiation and maturation and is 
not detected in the mature glomeruli and proximal tubules. One of the first molecular hallmarks of kidney regeneration is the reactivation of $\mathrm{Pax} 2$, as expression transiently reactivates in regenerating RTECs following acute tubular necrosis [93]. Using an ischemiareperfusion model reactivation of $\operatorname{Pax} 2$ in tubular cells after kidney injury was confirmed. BrdU/Pax 2 double-positive proliferating cells are regulated by activin $\mathrm{A}$, and this regulation is critical for the processes of tubular cell growth and differentiation during regeneration [94]. In addition, numerous studies agree that Pax 2 protects tubular cells from apoptosis. Zhang et al. employed an in-vitro approach using rat renal proximal cells and reported that knocking down pax2 increases cellular susceptibility to apoptosis [95]. Further evidence comes from of the analysis of Pax2 mutant mice [96]. The renal collecting ducts of heterozygous $\mathrm{Pax} 2^{1 \mathrm{Neu}}$ mice, when subject to unilateral ureteral obstruction (UUO), exhibit increased numbers of apoptotic cells when compared to wild-type mice [96]. Together, these data suggest an important role for Pax 2 in kidney regeneration by protecting renal epithelial cells from apoptosis initiated by injury.

Members of the LIM homeodomain (LIM-HD) family contain two LIM domains and a DNA binding homeodomain. Lhxl is the only family member to be expressed in all developing kidney types. Experiments in Xenopus laevis demonstrated that forced expression Lhxl increases the size of the pronephros. When Lhxl is overexpressed with Pax2 or Pax8 it induces the formation of ectopic pronephric tubules [97], consistent with an early and co-operative role for Pax2, Pax8, and Lhxla in pronephros formation. In support of this, Lhxl knockdown in the Xenopus laevis results in an early failure of pronephros development, and data suggest that Lhx1 might act as a competence factor necessary to establish the pronephric kidney field [98].

Homozygous null Lhxl mice, rarely live after birth and survivors lack head, gonads, and kidneys [99]. Homozygous null Lhxl mouse embryos also display disorganized intermediate mesoderm and are unable to properly form the nephric duct [100]. Using a floxed conditional $L h x l$ allele, it was found that $L h x l$ is required for the maintenance of the nephric duct and mesonephric tubules. In the developing metanephros, $L h x l$ is required for proper ureteric bud formation and patterning of renal vesicles during nephron formation [101]. Although molecular interactions between Lhx1 and a downstream target genes have not yet been reported in the kidney, the Wnt signaling inhibitor, Dkk1 was identified as a potential candidate [102].

The role of Lhx1 during kidney regeneration has not yet been studied extensively in mammalian models of AKI, but reactivation of its expression has been reported in rats subject to ischemia-reperfusion injury [10]. In regenerating proximal tubules, Lhxl transcripts are observed 48 hours post-damage and persists for a period of 24 hours in the regenerating proximal tubules [10]. Following injury, $\operatorname{Pax} 2$ and $L h x 1$ are serially reactivated, supporting a regenerative process in which nephrogenic proteins are reexpressed in a sequence of events similar to those that occur during metaneprhic kidney nephrogenesis [103]. In adult zebrafish mesonephric regeneration, following gentamicinmediated AKI, the new nephrons that formed were found to originate from cellular aggregates of potentially self-renewing progenitor cells that were marked by GFP driven by the lhxla promoter [30]. Following injury these progenitors activate expression of the nephrogenic genes wt $1 b$ and $f g f 8$, and undergo mesenchymal-to-epithelial transition into renal vesicles and new nephrons, supporting a role for Lhx1 in the process of regenerative neo-nephrogenesis. Further studies in mammals are required to demonstrate the importance of Lhx1 during metanephric kidney regeneration.

Sall proteins are a conserved family of transcription factors characterized by the presence of multiple double-zinc finger motifs [104]. These proteins play multiple roles during 
embryonic development including organogenesis and cell fate determination [105]. Most Sall proteins are expressed during vertebrate kidney organogenesis but with the exception of Sall1 little is known about their role in kidney development [106-109]. In humans Sall1 mutations leads to an autosomal dominant disease characterized by multiple birth defects including renal hypoplasia [110]. The function of sall during metanephric kidney development has been mainly studied using Sall1 knockout mice [111], however, mice carrying a mutant allele lacking the DNA binding domain, die during gestation and recapitulate the abnormalities found in humans with Townes-Brocks syndrome [112]. Homozygous mutant mice exhibit kidney agenesis as a result of failure in ureteric bud branching, and it is believed that Sall1 functions in the initial branching of the ureter by regulating canonical Wnt signaling in the uteretic bud cells. Wnt9b/ $\beta$-catenin signaling is reduced in the ureteric bud tip in the presence of Sall1, and this signaling event is required for proper branching [113].

Sall1 continues to be expressed in the adult metanephric kidney mainly in proximal tubule cells. Following ischemia-reperfusion injury approximately $90 \%$ of Sall1 positive cells proliferate and the levels of salll mRNA increase significantly between 4 and $12 \mathrm{~h}$ post injury [114]. Based on previous reports of Sall1 being a marker of renal progenitors in the metanephric mesenchyme [115] and the asymmetric division of sall1 expressing cells following injury, it has been proposed that Sall1 may be a marker of early proliferating renal progenitor cells necessary for replacing injured renal cells [114].

\section{Bmp signaling}

Representing the largest subfamily within the transforming growth factor beta superfamily, bone morphogenetic proteins (BMPs) are key inducers of the IM and emerging pronephros. Bmps emanating from the LPM and surrounding surface ectoderm form a gradient across the trunk mesoderm $[14,116]$. Intermediate Bmp concentrations within the IM overcome repressive factors from the adjacent PM, allowing the expression of Pax2, Lhxl, and Osrl [14]. Conditional expression of a Bmp inhibitor in Xenopus laevis embryos after formation of the IM causes severe malformations of the pronephric duct and tubules, consistent with a later requirement for BMPs in the differentiation of these cell types [117].

Transcripts for Bmps 2, 3, 4, 5, 6, and 7 have been observed in the mouse metanephros during various stages of its development [118]. Most mammalian studies have focused on the contributions of Bmps 2, 4, and 7 to metanephric kidney development [119]. Bmp7 null mice display a decreased number of metanephric mesenchymal condensates surrounding the ureteric bud and an overall reduction in branching morphogenesis [120]. Bmp7, acting together with Fgf2, maintains the responsiveness of the metanephric mesenchyme to inductive signals and prevents premature tubulogenesis [121]. Loss of Bmp7 has little effect on the expression of most nephrogenic genes, including Pax2, Pax8, Wnt4, and Wt1 [122, 123]. However, the lack of $B m p 7$ results in a drastic loss of mesenchymal progenitors expressing Six2 [120]. A specific deletion of Bmp 7 in podocytes results in hypoplastic kidneys with normal glomeruli but a reduced number of proximal tubules due to impaired proliferation [124]. Taken together these findings indicate Bmp7 may play multiple roles in the metanephric kidney including an antagonist of ureteric bud branching, cap mesenchyme survival, and as a stimulator of proximal tubule growth.

Mice carrying a homozygous null mutation for $B m p 2$ die before the formation of the IM [125]. Bmp2 heterozygous null mice undergo normal nephrogenesis and generate nephrons in similar quantities to wild type mice $[119,125]$. Bmp4 homozygous null mutant mice also die around gastrulation before the initiation of kidney development [126, 127]. However, unlike Bmp2, a number of Bmp4 heterozygous null mutants exhibit kidney cysts, cortical atrophy, and hydronephrosis when maintained on a C57BL/6 background [126]. Placing a 
Bmp4-coated bead near a ureteric bud in explant culture stimulates the growth and elongation of the bud [128] whereas branching is inhibited [129-131]. The observed response of ureteric buds to exogenous Bmp4, reflects the ability of Bmp4 to interfere with the differentiation of the metanephric mesenchyme and promote elongation of the ureter within the metanephros [131]. Secreted Bmp antagonists, including Noggin, Gremlin, and USAG-1, also contribute to normal metanephric development [119, 132-135]. These act by direct binding to Bmp proteins and precluding their binding to specific cell surface receptors modulating BMP signaling.

In the adult kidney of humans and rodents, $B m p 7$ is expressed by podocytes and medullary tubular epithelial cells $[136,137]$. Initially, two studies in rats subject to ischemiareperfusion injury observed significant down-regulation of Bmp 7 transcript levels suggesting modulation of its expression may be important for kidney repair [138, 139]. Following these studies, numerous groups investigated the effect of administration of exogenous human recombinant BMP7 (hrBMP7) during the regeneration process and demonstrated its ability to preserve kidney function following acute ischemic injury [140-143]. In rats, hrBMP7 reduces the inflammatory response and decreases tubular cell apoptosis when administered before or after damage [142]. In addition to its function as a renal homeostasis factor, it has been suggested that Bmp7 has a role in preventing tubulointerstitial fibrosis by inhibiting interstitial infiltration and fibroblast transformation [141, 144]. Bmp7 may also reverse epithelial-mesenchymal transition (EMT) of tubular epithelial cells in response to injury by re-inducing expression of the epithelial cell adhesion molecule, E-cadherin [145, 146]. In distal and proximal tubular epithelial cells subject to injury, hrBMP7 enhances the repair of the tubular structures [146]. Insights into the mechanism of action for Bmp7 suggest that it acts by counteracting TGF- $\beta$-fibrotic effect (Zeisberg et al., 2003b). The observation that Bmp7 has a reno-protective function during adult renal injury, suggests a conserved mechanism of action for Bmp7 in the processes of kidney organogenesis and regeneration. One question that remains to be elucidated is whether the antifibrotic effects of Bmp7 are specific for this Bmp or whether other Bmps have similar activities.

\section{Wnt signaling}

Wnt signaling can either proceed through canonical or non-canonical pathways, depending on the requirement for beta-catenin function (canonical pathway) [147]. During canonical signaling, Wnts bind a seven-pass transmembrane receptor, Frizzled, and an LDL receptorrelated protein (Lrp) 5 or 6 co-receptor [148]. This complex recruits the scaffolding protein, Dishevelled, resulting in phosphorylation of the associated Lrp [148]. Upon activation, Lrp sequesters the Axin complex to the membrane, preventing Axin from degrading cytosolic beta-catenin. This permits beta-catenin to translocate to the nucleus where it binds the TCF/ LEF family of transcription factors and activates target gene transcription [148]. Noncanonical Wnt pathways, including the planar cell polarity and calcium pathways, also transduce their signals through Dishevelled [147]. However, these pathways rely on the activation of downstream targets other than beta-catenin such as the GTPases Rho and Rac which in turn activate kinases that modulate cytoskeletal organization and transcription.

Work in Xenopus laevis has identified a key role for Wn4 in the development of the pronephros. Morpholino knockdown of Wnt4 reduces glomerular and tubule formation [149], whereas injections of increasing amounts of Wnt4 mRNA induce ectopic tubular structures [150]. Morpholino knockdown of the downstream Wnt/beta-catenin effector Lef1 in Xenopus tropicalis embryos also inhibited anterior tubulogenesis while decreasing the posterior expression of Pax2 [151]. Similarly, injection of a dominant-negative form of betacatenin resulted in a dose-dependent inhibition of pronephric tubule formation [152]. More 
severe effects are seen with injection of a dominant-negative form of Lef which causes a loss of all pronephric structures [152].,

Mice with homozygous null mutations in Wnt4, Wnt7b, Wnt9b, and Wnt11 all display abnormal metanephric kidney development [153-156]. Mice lacking Wnt4 show a complete lack of tubular development despite accumulation of cells at ureteric bud tips [155]. Those without Wnt7b show absence of the renal medulla, suggesting a role in establishing the corticomedullary axis [156]. Mice null for either Wnt9b or Wnt11 display disruptions in branching morphogenesis $[153,154]$. Loss of Wnt9b in mice prevents the expression of Wnt4, Fgf8, and Pax8, in the pretubular aggregates, resulting in decreased branching and tubulogenesis [153]. Therefore, Wnt9b likely functions upstream of Wnt4 during metanephric development, although proper renal vesicle formation requires the expression of both genes [153]. Besides its role in nephron development, canonical Wnt signaling pathway is important during ureteric budding and branching morphogenesis [157, 158]. Wnt11 expression in the ureteric epithelium reciprocally induces Ret/Gdnf signaling in the surrounding mesenchyme maintaining branching morphogenesis [154]. Therefore, input from both the canonical (Wnt4, Wnt7b, and Wnt9) and non-canonical (Wnt11) pathways control the development of the metanephric kidney.

Although Wnt expression is down-regulated in the adult kidney [159], current research suggests that $\mathrm{Wnt} /$ beta-catenin signaling pathway is reactivated during kidney regeneration. The initial observation of Wnt4 reactivation was reported in a UUO model in rats [160], while Wnt4 reactivation also was reported in the collecting duct epithelium and surrounding interstitial cells in a model of AKI induced by folic acid treatment [161]. The mRNA levels of Wnt 4 during the recovery phase of ischemia-reperfusion were transiently up-regulated in proximal tubular cells as early as 6 hours post injury and back to baseline levels by 24 hours post injury [47]. Increased levels of Wnt4 correlated with increased protein levels of CyclinD1 and CyclinA implies that Wnt 4 might be promoting tubular cell proliferation via control of cyclins, and this ability of Wnt4 to induce cell cycle progression in a renal epithelial cells is mediated by beta-catenin [47]. However, adding to the complexity of the role of Wnt 4 following injury, a recent study using a Wnt4 reporter transgenic mouse line, following ischemia-reperfusion injury, finds Wnt4 reactivation in interstitial myofibroblasts and not in tubular epithelium [162].

Evidence suggests that Wnt signaling from macrophages, contributes to kidney regeneration [163]. Several days after ischemia-reperfusion injury, surviving proximal tubule epithelial cells become Wnt responsive, and activated renal macrophages are a source of the ligand Wnt7b. Macrophage production of pro-survival factors could be key in the regeneration process possibly by preserving basement membrane integrity and preventing apoptotic cell death of RTECs, revealing the participation of non-tubular cells in the events that initiate tubular repair and regeneration after injury [163]. Even though the mechanistic details of Wnt-signaling activation remain to be elucidated, the Wnt-pathway appears to promote cell survival and enhance regeneration of the damaged tubule.

\section{Conclusions}

The reactivation of multiple embryonic signaling pathways during kidney regeneration has driven the hypothesis that these pathways play similar roles in both the specification and replacement of renal tissue (Figure 1, Table 1) [7-10]. As presented in this review, regeneration mediated cell proliferation and morphogenesis coincides with the reactivation of genes normally associated with kidney organogenesis, suggesting that regenerating tubular epithelium may be reprogrammed to a less-differentiated, multi-potent state. However, there is much yet to be elucidated regarding the mechanisms driving kidney 
regeneration. The AKI studies to date are based mainly upon expression of reactivated genes and not how those genes influence regenerative events [8-10]. These nascent reactivation studies are similar to early embryonic expression studies. The goal of several large scale embryonic expression studies was to identify new genes with unique expression patterns during tissue and organ development, and from that initial starting point the mechanistic role of the newly identified genes was eventually deciphered [164-166]. In addition to deciphering the mechanistic role signaling pathways play during regeneration, understanding the temporal component of gene reactivation will also be important to determining how scientists can influence regenerative events. The multitude of published renal embryonic mechanistic studies are a good place to take cues from to further the understanding of the etiology of renal damage, identify new therapeutic treatments, and advance the cell replacement and tissue engineering fields.

\section{Acknowledgments}

Supported by grants from the National Institutes of Health, NAH: 2R01 DK069403, 2R01 HD053287, 1P30 DK079307; MPdC: 1RO1 HL093057, 1P30 DK079341; NAH/MPdC 1RC4 DK090770; AJD: The Rutherford Foundation Trust and the Marsden Fund of New Zealand.

\section{References}

1. Hoffman PN, Cleveland DW. Neurofilament and tubulin expression recapitulates the developmental program during axonal regeneration: induction of a specific beta-tubulin isotype. Proc Natl Acad Sci U S A. 1988; 85:4530-4533. [PubMed: 3132717]

2. Tsonis PA. Regeneration in vertebrates. Dev Biol. 2000; 221:273-284. [PubMed: 10790325]

3. Tseng AS, Levin M. Tail regeneration in Xenopus laevis as a model for understanding tissue repair. J Dent Res. 2008; 87:806-816. [PubMed: 18719206]

4. Liu Y. Cellular and molecular mechanisms of renal fibrosis. Nat Rev Nephrol. 2011; 7:684-696. [PubMed: 22009250]

5. Murugan R, Kellum JA. Acute kidney injury: what's the prognosis? Nat Rev Nephrol. 2011; 7:209_ 217. [PubMed: 21343898]

6. Vogetseder A, Picard N, Gaspert A, Walch M, Kaissling B, Le Hir M. Proliferation capacity of the renal proximal tubule involves the bulk of differentiated epithelial cells. Am J Physiol Cell Physiol. 2008; 294:C22-C28. [PubMed: 17913845]

7. Davidson AJ. Uncharted waters: nephrogenesis and renal regeneration in fish and mammals. Pediatr Nephrol. 2011; 26:1435-1443. [PubMed: 21336813]

8. Basile DP, Hammerman MR. TGF-beta in renal development and renal growth. Miner Electrolyte Metab. 1998; 24:144-148. [PubMed: 9525697]

9. Guo JK, Cantley LG. Cellular maintenance and repair of the kidney. Annu Rev Physiol. 2010; 72:357-376. [PubMed: 20148680]

10. Villanueva S, Cespedes C, Vio CP. Ischemic acute renal failure induces the expression of a wide range of nephrogenic proteins. Am J Physiol Regul Integr Comp Physiol. 2006; 290:R861-R870. [PubMed: 16284088]

11. Al-Awqati Q, Oliver JA. Stem cells in the kidney. Kidney Int. 2002; 61:387-395. [PubMed: 11849378]

12. Saxen L, Sariola H. Early organogenesis of the kidney. Pediatr Nephrol. 1987; 1:385-392. [PubMed: 3153305]

13. James RG, Kamei CN, Wang Q, Jiang R, Schultheiss TM. Odd-skipped related 1 is required for development of the metanephric kidney and regulates formation and differentiation of kidney precursor cells. Development. 2006; 133:2995-3004. [PubMed: 16790474]

14. James RG, Schultheiss TM. Bmp signaling promotes intermediate mesoderm gene expression in a dose-dependent, cell-autonomous and translation-dependent manner. Dev Biol. 2005; 288:113125. [PubMed: 16243309] 
15. Mauch TJ, Yang G, Wright M, Smith D, Schoenwolf GC. Signals from trunk paraxial mesoderm induce pronephros formation in chick intermediate mesoderm. Dev Biol. 2000; 220:62-75. [PubMed: 10720431]

16. Vize PD. The chloride conductance channel ClC-K is a specific marker for the Xenopus pronephric distal tubule and duct. Gene Expr Patterns. 2003; 3:347-350. [PubMed: 12799083]

17. Fox H. The amphibian pronephros. Q Rev Biol. 1963; 38:1-25. [PubMed: 13959024]

18. Marshman E, Booth C, Potten CS. The intestinal epithelial stem cell. Bioessays. 2002; 24:91-98. [PubMed: 11782954]

19. Goldstein J, Horsley V. Home sweet home: skin stem cell niches. Cell Mol Life Sci. 2012

20. Lameire N, Van Biesen W, Vanholder R. The changing epidemiology of acute renal failure. Nat Clin Pract Nephrol. 2006; 2:364-377. [PubMed: 16932465]

21. Kaushal GP, Basnakian AG, Shah SV. Apoptotic pathways in ischemic acute renal failure. Kidney Int. 2004; 66:500-506. [PubMed: 15253697]

22. Sheridan AM, Bonventre JV. Cell biology and molecular mechanisms of injury in ischemic acute renal failure. Curr Opin Nephrol Hypertens. 2000; 9:427-434. [PubMed: 10926180]

23. Thadhani R, Pascual M, Bonventre JV. Acute renal failure. N Engl J Med. 1996; 334:1448-1460. [PubMed: 8618585]

24. Lash LH. Renal membrane transport of glutathione in toxicology and disease. Vet Pathol. 2011; 48:408-419. [PubMed: 20656901]

25. Goligorsky MS, Lieberthal W, Racusen L, Simon EE. Integrin receptors in renal tubular epithelium: new insights into pathophysiology of acute renal failure. Am J Physiol. 1993; 264:F1F8. [PubMed: 8430820]

26. Molitoris BA, Marrs J. The role of cell adhesion molecules in ischemic acute renal failure. Am J Med. 1999; 106:583-592. [PubMed: 10335732]

27. Cianciolo Cosentino C, Roman BL, Drummond IA, Hukriede NA. Intravenous microinjections of zebrafish larvae to study acute kidney injury. Journal of visualized experiments : J Vis Exp. 2010; (42):2079.

28. Cianciolo Cosentino C, Skrypnyk NI, Brilli LL, Chiba T, Novitskaya T, Woods C, West J, Korotchenko VN, McDermott L, Day BW, Davidson AJ, Harris RC, de Caestecker MP, Hukriede NA. Histone Deacetylase Inhibitor Enhances Recovery after AKI. J Am Soc Nephrol. 2013; 24:943-953. [PubMed: 23620402]

29. Hentschel DM, Park KM, Cilenti L, Zervos AS, Drummond I, Bonventre JV. Acute renal failure in zebrafish: a novel system to study a complex disease. Am J Physiol Renal Physiol. 2005; 288:F923-F929. [PubMed: 15625083]

30. Diep CQ, Ma D, Deo RC, Holm TM, Naylor RW, Arora N, Wingert RA, Bollig F, Djordjevic G, Lichman B, Zhu H, Ikenaga T, Ono F, Englert C, Cowan CA, Hukriede NA, Handin RI, Davidson AJ. Identification of adult nephron progenitors capable of kidney regeneration in zebrafish. Nature. 2011; 470:95-100. [PubMed: 21270795]

31. Vogetseder A, Palan T, Bacic D, Kaissling B, Le Hir M. Proximal tubular epithelial cells are generated by division of differentiated cells in the healthy kidney. Am J Physiol Cell Physiol. 2007; 292:C807-C813. [PubMed: 16987990]

32. Belleri M, Ribatti D, Nicoli S, Cotelli F, Forti L, Vannini V, Stivala LA, Presta M. Antiangiogenic and vascular-targeting activity of the microtubule-destabilizing trans-resveratrol derivative 3,5,4'trimethoxystilbene. Mol Pharmacol. 2005; 67:1451-1459. [PubMed: 15703378]

33. Verghese E, Weidenfeld R, Bertram JF, Ricardo SD, Deane JA. Renal cilia display length alterations following tubular injury and are present early in epithelial repair. Nephrol Dial Transplant. 2008; 23:834-841. [PubMed: 17962379]

34. Witzgall R, Brown D, Schwarz C, Bonventre JV. Localization of proliferating cell nuclear antigen, vimentin, c-Fos, and clusterin in the postischemic kidney. Evidence for a heterogenous genetic response among nephron segments, and a large pool of mitotically active and dedifferentiated cells. J Clin Invest. 1994; 93:2175-2188. [PubMed: 7910173]

35. Humphreys BD, Valerius MT, Kobayashi A, Mugford JW, Soeung S, Duffield JS, McMahon AP, Bonventre JV. Intrinsic epithelial cells repair the kidney after injury. Cell Stem Cell. 2008; 2:284291. [PubMed: 18371453] 
36. Maeshima A, Yamashita S, Nojima Y. Identification of renal progenitor-like tubular cells that participate in the regeneration processes of the kidney. J Am Soc Nephrol. 2003; 14:3138-3146. [PubMed: 14638912]

37. Cantz T, Manns MP, Ott M. Stem cells in liver regeneration and therapy. Cell Tissue Res. 2008; 331:271-282. [PubMed: 17901986]

38. Stripp BR, Reynolds SD. Maintenance and repair of the bronchiolar epithelium. Proc Am Thorac Soc. 2008; 5:328-333. [PubMed: 18403328]

39. Teta M, Rankin MM, Long SY, Stein GM, Kushner JA. Growth and regeneration of adult beta cells does not involve specialized progenitors. Dev Cell. 2007; 12:817-826. [PubMed: 17488631]

40. Lazzeri E, Crescioli C, Ronconi E, Mazzinghi B, Sagrinati C, Netti GS, Angelotti ML, Parente E, Ballerini L, Cosmi L, Maggi L, Gesualdo L, Rotondi M, Annunziato F, Maggi E, Lasagni L, Serio M, Romagnani S, Vannelli GB, Romagnani P. Regenerative potential of embryonic renal multipotent progenitors in acute renal failure. J Am Soc Nephrol. 2007; 18:3128-3138. [PubMed: 17978305]

41. Hopkins C, Li J, Rae F, Little MH. Stem cell options for kidney disease. J Pathol. 2009; 217:265281. [PubMed: 19058290]

42. Pleniceanu O, Harari-Steinberg O, Dekel B. Concise review: Kidney stem/progenitor cells: differentiate, sort out, or reprogram? Stem Cells. 2010; 28:1649-1660. [PubMed: 20652959]

43. Sagrinati C, Ronconi E, Lazzeri E, Lasagni L, Romagnani P. Stem-cell approaches for kidney repair: choosing the right cells. Trends Mol Med. 2008; 14:277-285. [PubMed: 18554984]

44. Zubko R, Frishman W. Stem cell therapy for the kidney? Am J Ther. 2009; 16:247-256. [PubMed: 19092639]

45. Kobayashi T, Terada Y, Kuwana H, Tanaka H, Okado T, Kuwahara M, Tohda S, Sakano S, Sasaki $\mathrm{S}$. Expression and function of the Delta-1/Notch-2/Hes-1 pathway during experimental acute kidney injury. Kidney Int. 2008; 73:1240-1250. [PubMed: 18418349]

46. Lin F, Moran A, Igarashi P. Intrarenal cells, not bone marrow-derived cells, are the major source for regeneration in postischemic kidney. J Clin Invest. 2005; 115:1756-1764. [PubMed: 16007252]

47. Terada Y, Tanaka H, Okado T, Shimamura H, Inoshita S, Kuwahara M, Sasaki S. Expression and function of the developmental gene Wnt-4 during experimental acute renal failure in rats. J Am Soc Nephrol. 2003; 14:1223-1233. [PubMed: 12707392]

48. Duester G. Retinoic acid synthesis and signaling during early organogenesis. Cell. 2008; 134:921931. [PubMed: 18805086]

49. Ross SA, McCaffery PJ, Drager UC, De Luca LM. Retinoids in embryonal development. Physiol Rev. 2000; 80:1021-1054. [PubMed: 10893430]

50. Marill J, Idres N, Capron CC, Nguyen E, Chabot GG. Retinoic acid metabolism and mechanism of action: a review. Curr Drug Metab. 2003; 4:1-10. [PubMed: 12570742]

51. Chambon P. The retinoid signaling pathway: molecular and genetic analyses. Semin Cell Biol. 1994; 5:115-125. [PubMed: 8068884]

52. Kastner P, Mark M, Ghyselinck N, Krezel W, Dupe V, Grondona JM, Chambon P. Genetic evidence that the retinoid signal is transduced by heterodimeric RXR/RAR functional units during mouse development. Development. 1997; 124:313-326. [PubMed: 9053308]

53. Cartry J, Nichane M, Ribes V, Colas A, Riou JF, Pieler T, Dolle P, Bellefroid EJ, Umbhauer M. Retinoic acid signalling is required for specification of pronephric cell fate. Dev Biol. 2006; 299:35-51. [PubMed: 16979153]

54. Taira M, Jamrich M, Good PJ, Dawid IB. The LIM domain-containing homeo box gene Xlim-1 is expressed specifically in the organizer region of Xenopus gastrula embryos. Genes Dev. 1992; 6:356-366. [PubMed: 1347750]

55. Moriya N, Uchiyama H, Asashima M. Induction of pronephric tubules by activin and retinoic acid in presumptive ectoderm of Xenopus laevis. Dev Growth Differ. 1993; 35:123-128.

56. Osafune K, Nishinakamura R, Komazaki S, Asashima M. In vitro induction of the pronephric duct in Xenopus explants. Dev Growth Differ. 2002; 44:161-167. [PubMed: 11940102] 
57. Taira M, Otani H, Jamrich M, Dawid IB. Expression of the LIM class homeobox gene Xlim-1 in pronephros and CNS cell lineages of Xenopus embryos is affected by retinoic acid and exogastrulation. Development. 1994; 120:1525-1536. [PubMed: 7914163]

58. Wingert RA, Selleck R, Yu J, Song HD, Chen Z, Song A, Zhou Y, Thisse B, Thisse C, McMahon AP, Davidson AJ. The cdx genes and retinoic acid control the positioning and segmentation of the zebrafish pronephros. PLoS Genet. 2007; 3:1922-1938. [PubMed: 17953490]

59. Preger-Ben Noon E, Barak H, Guttmann-Raviv N, Reshef R. Interplay between activin and Hox genes determines the formation of the kidney morphogenetic field. Development. 2009; 136:19952004. [PubMed: 19439491]

60. Wingert RA, Davidson AJ. Zebrafish nephrogenesis involves dynamic spatiotemporal expression changes in renal progenitors and essential signals from retinoic acid and irx3b. Dev Dyn. 2011; 240:2011-2027. [PubMed: 21761484]

61. Lelievre-Pegorier M, Vilar J, Ferrier ML, Moreau E, Freund N, Gilbert T, Merlet-Benichou C. Mild vitamin A deficiency leads to inborn nephron deficit in the rat. Kidney Int. 1998; 54:14551462. [PubMed: 9844121]

62. Wilson JG, Roth CB, Warkany J. An analysis of the syndrome of malformations induced by maternal vitamin A deficiency. Effects of restoration of vitamin A at various times during gestation. Am J Anat. 1953; 92:189-217. [PubMed: 13030424]

63. Wilson JG, Warkany J. Malformations in the genito-urinary tract induced by maternal vitamin A deficiency in the rat. Am J Anat. 1948; 83:357-407. [PubMed: 18098411]

64. Mendelsohn C, Lohnes D, Decimo D, Lufkin T, LeMeur M, Chambon P, Mark M. Function of the retinoic acid receptors (RARs) during development (II). Multiple abnormalities at various stages of organogenesis in RAR double mutants. Development. 1994; 120:2749-2771. [PubMed: 7607068]

65. Batourina E, Gim S, Bello N, Shy M, Clagett-Dame M, Srinivas S, Costantini F, Mendelsohn C. Vitamin A controls epithelial/mesenchymal interactions through Ret expression. Nat Genet. 2001; 27:74-78. [PubMed: 11138002]

66. Huang CC, Huang JK. Sepsis-induced acute bilateral renal cortical necrosis. Nephrology (Carlton). 2011; 16:787. [PubMed: 22029648]

67. Takenaga M, Ohta Y, Tokura Y, Hamaguchi A, Shudo K, Okano H, Igarashi R. The effect of Am-80, a synthetic retinoid, on spinal cord injury-induced motor dysfunction in rats. Biol Pharm Bull. 2009; 32:225-231. [PubMed: 19182380]

68. van Neerven S, Mey J, Joosten EA, Steinbusch HW, van Kleef M, Marcus MA, Deumens R. Systemic but not local administration of retinoic acid reduces early transcript levels of proinflammatory cytokines after experimental spinal cord injury. Neurosci Lett. 2010; 485:21-25. [PubMed: 20736048]

69. Wong LF, Yip PK, Battaglia A, Grist J, Corcoran J, Maden M, Azzouz M, Kingsman SM, Kingsman AJ, Mazarakis ND, McMahon SB. Retinoic acid receptor beta2 promotes functional regeneration of sensory axons in the spinal cord. Nat Neurosci. 2006; 9:243-250. [PubMed: 16388307]

70. Yip PK, Wong LF, Pattinson D, Battaglia A, Grist J, Bradbury EJ, Maden M, McMahon SB, Mazarakis ND. Lentiviral vector expressing retinoic acid receptor beta2 promotes recovery of function after corticospinal tract injury in the adult rat spinal cord. Hum Mol Genet. 2006; 15:3107-3118. [PubMed: 16984961]

71. Massaro GD, Massaro D. Retinoic acid treatment abrogates elastase-induced pulmonary emphysema in rats. Nat Med. 1997; 3:675-677. [PubMed: 9176496]

72. Tepper J, Pfeiffer J, Aldrich M, Tumas D, Kern J, Hoffman E, McLennan G, Hyde D. Can retinoic acid ameliorate the physiologic and morphologic effects of elastase instillation in the rat? Chest. 2000; 117:242S-244S. [PubMed: 10843928]

73. Stinchcombe SV, Maden M. Retinoic acid induced alveolar regeneration: critical differences in strain sensitivity. Am J Respir Cell Mol Biol. 2008; 38:185-191. [PubMed: 17717321]

74. Kikuchi K, Holdway JE, Major RJ, Blum N, Dahn RD, Begemann G, Poss KD. Retinoic acid production by endocardium and epicardium is an injury response essential for zebrafish heart regeneration. Devel Cell. 2011; 20:397-404. [PubMed: 21397850] 
75. Stuckmann I, Evans S, Lassar AB. Erythropoietin and retinoic acid, secreted from the epicardium, are required for cardiac myocyte proliferation. Devel Biol. 2003; 255:334-349. [PubMed: 12648494]

76. Wagner J, Dechow C, Morath C, Lehrke I, Amann K, Waldherr R, Floege J, Ritz E. Retinoic acid reduces glomerular injury in a rat model of glomerular damage. J Am Soc Nephrol. 2000; 11:1479-1487. [PubMed: 10906161]

77. Suzuki A, Ito T, Imai E, Yamato M, Iwatani H, Kawachi H, Hori M. Retinoids regulate the repairing process of the podocytes in puromycin aminonucleoside-induced nephrotic rats. $\mathrm{J}$ Am Soc Nephrol. 2003; 14:981-991. [PubMed: 12660332]

78. Perez A, Ramirez-Ramos M, Calleja C, Martin D, Namorado MC, Sierra G, Ramirez-Ramos ME, Paniagua R, Sanchez Y, Arreola L, Reyes JL. Beneficial effect of retinoic acid on the outcome of experimental acute renal failure. Nephrol Dial Transplant. 2004; 19:2464-2471. [PubMed: 15316095]

79. Frigerio G, Burri M, Bopp D, Baumgartner S, Noll M. Structure of the segmentation gene paired and the Drosophila PRD gene set as part of a gene network. Cell. 1986; 47:735-746. [PubMed: 2877746]

80. Asano M, Gruss P. Pax-5 is expressed at the midbrain-hindbrain boundary during mouse development. Mech Dev. 1992; 39:29-39. [PubMed: 1283313]

81. Dressler GR, Deutsch U, Chowdhury K, Nornes HO, Gruss P. Pax2, a new murine paired-boxcontaining gene and its expression in the developing excretory system. Development. 1990; 109:787-795. [PubMed: 1977574]

82. Plachov D, Chowdhury K, Walther C, Simon D, Guenet JL, Gruss P. Pax8, a murine paired box gene expressed in the developing excretory system and thyroid gland. Development. 1990; 110:643-651. [PubMed: 1723950]

83. Mansouri A, Chowdhury K, Gruss P. Follicular cells of the thyroid gland require Pax 8 gene function. Nat Genet. 1998; 19:87-90. [PubMed: 9590297]

84. Torres M, Gomez-Pardo E, Dressler GR, Gruss P. Pax-2 controls multiple steps of urogenital development. Development. 1995; 121:4057-4065. [PubMed: 8575306]

85. Bouchard M, Souabni A, Mandler M, Neubuser A, Busslinger M. Nephric lineage specification by Pax2 and Pax8. Genes Dev. 2002; 16:2958-2970. [PubMed: 12435636]

86. Majumdar A, Lun K, Brand M, Drummond IA. Zebrafish no isthmus reveals a role for pax 2.1 in tubule differentiation and patterning events in the pronephric primordia. Development. 2000; 127:2089-2098. [PubMed: 10769233]

87. Sainio K, Suvanto P, Davies J, Wartiovaara J, Wartiovaara K, Saarma M, Arumae U, Meng X, Lindahl M, Pachnis V, Sariola H. Glial-cell-line-derived neurotrophic factor is required for bud initiation from ureteric epithelium. Development. 1997; 124:4077-4087. [PubMed: 9374404]

88. Vega QC, Worby CA, Lechner MS, Dixon JE, Dressler GR. Glial cell line-derived neurotrophic factor activates the receptor tyrosine kinase RET and promotes kidney morphogenesis. Proc Natl Acad Sci U S A. 1996; 93:10657-10661. [PubMed: 8855235]

89. Brophy PD, Ostrom L, Lang KM, Dressler GR. Regulation of ureteric bud outgrowth by Pax2dependent activation of the glial derived neurotrophic factor gene. Development. 2001; 128:47474756. [PubMed: 11731455]

90. Gong KQ, Yallowitz AR, Sun H, Dressler GR, Wellik DM. A Hox-Eya-Pax complex regulates early kidney developmental gene expression. Mol Cell Biol. 2007; 27:7661-7668. [PubMed: 17785448]

91. Clarke JC, Patel SR, Raymond RM Jr, Andrew S, Robinson BG, Dressler GR, Brophy PD. Regulation of c-Ret in the developing kidney is responsive to Pax2 gene dosage. Hum Mol Genet. 2006; 15:3420-3428. [PubMed: 17047028]

92. Narlis M, Grote D, Gaitan Y, Boualia SK, Bouchard M. Pax2 and pax8 regulate branching morphogenesis and nephron differentiation in the developing kidney. J Am Soc Nephrol. 2007; 18:1121-1129. [PubMed: 17314325]

93. Imgrund M, Grone E, Grone HJ, Kretzler M, Holzman L, Schlondorff D, Rothenpieler UW. Reexpression of the developmental gene Pax-2 during experimental acute tubular necrosis in mice 1 . Kidney Int. 1999; 56:1423-1431. [PubMed: 10504494] 
94. Maeshima A, Maeshima K, Nojima Y, Kojima I. Involvement of Pax-2 in the action of activin A on tubular cell regeneration. J Am Soc Nephrol. 2002; 13:2850-2859. [PubMed: 12444203]

95. Zhang SL, Guo J, Moini B, Ingelfinger JR. Angiotensin II stimulates Pax-2 in rat kidney proximal tubular cells: impact on proliferation and apoptosis. Kidney Int. 2004; 66:2181-2192. [PubMed: 15569307]

96. Cohen T, Loutochin O, Amin M, Capolicchio JP, Goodyer P, Jednak R. PAX2 is reactivated in urinary tract obstruction and partially protects collecting duct cells from programmed cell death. Am J Physiol Renal Physiol. 2007; 292:F1267-F1273. [PubMed: 17164400]

97. Carroll TJ, Vize PD. Synergism between Pax-8 and lim-1 in embryonic kidney development. Dev Biol. 1999; 214:46-59. [PubMed: 10491256]

98. Cirio MC, Hui Z, Haldin CE, Cosentino CC, Stuckenholz C, Chen X, Hong SK, Dawid IB, Hukriede NA. Lhx1 is required for specification of the renal progenitor cell field. PLoS One. 2011; 6:e18858. [PubMed: 21526205]

99. Shawlot W, Behringer RR. Requirement for Lim1 in head-organizer function. Nature. 1995; 374:425-430. [PubMed: 7700351]

100. Tsang TE, Shawlot W, Kinder SJ, Kobayashi A, Kwan KM, Schughart K, Kania A, Jessell TM, Behringer RR, Tam PP. Lim1 activity is required for intermediate mesoderm differentiation in the mouse embryo. Dev Biol. 2000; 223:77-90. [PubMed: 10864462]

101. Kobayashi A, Kwan KM, Carroll TJ, McMahon AP, Mendelsohn CL, Behringer RR. Distinct and sequential tissue-specific activities of the LIM-class homeobox gene Lim1 for tubular morphogenesis during kidney development. Development. 2005; 132:2809-2823. [PubMed: 15930111]

102. Potter SS, Hartman HA, Kwan KM, Behringer RR, Patterson LT. Laser capture-microarray analysis of Lim1 mutant kidney development. Genesis. 2007; 45:432-439. [PubMed: 17610272]

103. Karavanov AA, Karavanova I, Perantoni A, Dawid IB. Expression pattern of the rat Lim-1 homeobox gene suggests a dual role during kidney development. Int J Dev Biol. 1998; 42:61-66. [PubMed: 9496787]

104. Kuhnlein RP, Frommer G, Friedrich M, Gonzalez-Gaitan M, Weber A, Wagner-Bernholz JF, Gehring WJ, Jackle H, Schuh R. spalt encodes an evolutionarily conserved zinc finger protein of novel structure which provides homeotic gene function in the head and tail region of the Drosophila embryo. EMBO J. 1994; 13:168-179. [PubMed: 7905822]

105. de Celis JF, Barrio R. Regulation and function of Spalt proteins during animal development. Int J Dev Biol. 2009; 53:1385-1398. [PubMed: 19247946]

106. Onuma Y, Nishinakamura R, Takahashi S, Yokota T, Asashima M. Molecular cloning of a novel Xenopus spalt gene (Xsal-3). Biochem Biophys Res Commun. 1999; 264:151-156. [PubMed: 10527856]

107. Hollemann T, Schuh R, Pieler T, Stick R. Xenopus Xsal-1, a vertebrate homolog of the region specific homeotic gene spalt of Drosophila. Mech Dev. 1996; 55:19-32. [PubMed: 8734496]

108. Farrell ER, Tosh G, Church E, Munsterberg AE. Cloning and expression of CSAL2, a new member of the spalt gene family in chick. Mech Dev. 2001; 102:227-230. [PubMed: 11287198]

109. Camp E, Hope R, Kortschak RD, Cox TC, Lardelli M. Expression of three spalt (sal) gene homologues in zebrafish embryos. Dev Genes Evol. 2003; 213:35-43. [PubMed: 12590351]

110. Kohlhase J, Wischermann A, Reichenbach H, Froster U, Engel W. Mutations in the SALL1 putative transcription factor gene cause Townes-Brocks syndrome. Nat Genet. 1998; 18:81-83. [PubMed: 9425907]

111. Nishinakamura R, Matsumoto Y, Nakao K, Nakamura K, Sato A, Copeland NG, Gilbert DJ, Jenkins NA, Scully S, Lacey DL, Katsuki M, Asashima M, Yokota T. Murine homolog of SALL1 is essential for ureteric bud invasion in kidney development. Development. 2001; 128:3105-3115. [PubMed: 11688560]

112. Kiefer SM, Ohlemiller KK, Yang J, McDill BW, Kohlhase J, Rauchman M. Expression of a truncated Sall1 transcriptional repressor is responsible for Townes-Brocks syndrome birth defects. Hum Mol Genet. 2003; 12:2221-2227. [PubMed: 12915476] 
113. Kiefer SM, Robbins L, Stumpff KM, Lin C, Ma L, Rauchman M. Sall1-dependent signals affect Wnt signaling and ureter tip fate to initiate kidney development. Development. 2010; 137:30993106. [PubMed: 20702564]

114. Abedin MJ, Imai N, Rosenberg ME, Gupta S. Identification and characterization of Sall1expressing cells present in the adult mouse kidney. Nephron Exp Nephrol. 2011; 119:e75-e82. [PubMed: 21934330]

115. Osafune K, Takasato M, Kispert A, Asashima M, Nishinakamura R. Identification of multipotent progenitors in the embryonic mouse kidney by a novel colony-forming assay. Development. 2006; 133:151-161. [PubMed: 16319116]

116. Obara-Ishihara T, Kuhlman J, Niswander L, Herzlinger D. The surface ectoderm is essential for nephric duct formation in intermediate mesoderm. Development. 1999; 126:1103-1108. [PubMed: 10021330]

117. Bracken CM, Mizeracka K, McLaughlin KA. Patterning the embryonic kidney: BMP signaling mediates the differentiation of the pronephric tubules and duct in Xenopus laevis. Dev Dyn. 2008; 237:132-144. [PubMed: 18069689]

118. Dudley AT, Robertson EJ. Overlapping expression domains of bone morphogenetic protein family members potentially account for limited tissue defects in BMP7 deficient embryos. Dev Dyn. 1997; 208:349-362. [PubMed: 9056639]

119. Martinez G, Mishina Y, Bertram JF. BMPs and BMP receptors in mouse metanephric development: in vivo and in vitro studies. Int J Dev Biol. 2002; 46:525-533. [PubMed: 12141440]

120. Goncalves A, Zeller R. Genetic analysis reveals an unexpected role of BMP7 in initiation of ureteric bud outgrowth in mouse embryos. PLoS One. 2011; 6:e19370. [PubMed: 21552539]

121. Dudley AT, Godin RE, Robertson EJ. Interaction between FGF and BMP signaling pathways regulates development of metanephric mesenchyme. Genes Dev. 1999; 13:1601-1613. [PubMed: 10385628]

122. Dudley AT, Lyons KM, Robertson EJ. A requirement for bone morphogenetic protein-7 during development of the mammalian kidney and eye. Genes Dev. 1995; 9:2795-2807. [PubMed: 7590254]

123. Luo G, Hofmann C, Bronckers AL, Sohocki M, Bradley A, Karsenty G. BMP-7 is an inducer of nephrogenesis, and is also required for eye development and skeletal patterning. Genes Dev. 1995; 9:2808-2820. [PubMed: 7590255]

124. Kazama I, Mahoney Z, Miner JH, Graf D, Economides AN, Kreidberg JA. Podocyte-derived BMP7 is critical for nephron development. J Am Soc Nephrol. 2008; 19:2181-2191. [PubMed: 18923055]

125. Zhang C, Evans T. BMP-like signals are required after the midblastula transition for blood cell development. Dev Genet. 1996; 18:267-278. [PubMed: 8631160]

126. Dunn NR, Winnier GE, Hargett LK, Schrick JJ, Fogo AB, Hogan BL. Haploinsufficient phenotypes in Bmp4 heterozygous null mice and modification by mutations in Gli3 and Alx4. Dev Biol. 1997; 188:235-247. [PubMed: 9268572]

127. Winnier G, Blessing M, Labosky PA, Hogan BL. Bone morphogenetic protein-4 is required for mesoderm formation and patterning in the mouse. Genes Dev. 1995; 9:2105-2116. [PubMed: 7657163]

128. Miyazaki Y, Oshima K, Fogo A, Hogan BL, Ichikawa I. Bone morphogenetic protein 4 regulates the budding site and elongation of the mouse ureter. J Clin Invest. 2000; 105:863-873. [PubMed: 10749566]

129. Cain JE, Bertram JF. Ureteric branching morphogenesis in BMP4 heterozygous mutant mice. J Anat. 2006; 209:745-755. [PubMed: 17118062]

130. Cain JE, Nion T, Jeulin D, Bertram JF. Exogenous BMP-4 amplifies asymmetric ureteric branching in the developing mouse kidney in vitro. Kidney Int. 2005; 67:420-431. [PubMed: 15673289]

131. Raatikainen-Ahokas A, Hytonen M, Tenhunen A, Sainio K, Sariola H. BMP-4 affects the differentiation of metanephric mesenchyme and reveals an early anterior-posterior axis of the embryonic kidney. Dev Dyn. 2000; 217:146-158. [PubMed: 10706139] 
132. Michos O, Goncalves A, Lopez-Rios J, Tiecke E, Naillat F, Beier K, Galli A, Vainio S, Zeller R. Reduction of BMP4 activity by gremlin 1 enables ureteric bud outgrowth and GDNF/WNT11 feedback signalling during kidney branching morphogenesis. Development. 2007; 134:23972405. [PubMed: 17522159]

133. Michos O, Panman L, Vintersten K, Beier K, Zeller R, Zuniga A. Gremlin-mediated BMP antagonism induces the epithelial-mesenchymal feedback signaling controlling metanephric kidney and limb organogenesis. Development. 2004; 131:3401-3410. [PubMed: 15201225]

134. Ueda H, Miyazaki Y, Matsusaka T, Utsunomiya Y, Kawamura T, Hosoya T, Ichikawa I. Bmp in podocytes is essential for normal glomerular capillary formation. J Am Soc Nephrol. 2008; 19:685-694. [PubMed: 18272846]

135. Yanagita M, Oka M, Watabe T, Iguchi H, Niida A, Takahashi S, Akiyama T, Miyazono K, Yanagisawa M, Sakurai T. USAG-1: a bone morphogenetic protein antagonist abundantly expressed in the kidney. Biochem Biophys Res Commun. 2004; 316:490-500. [PubMed: 15020244]

136. Kopp JB. BMP receptors in kidney. Kidney Int. 2000; 58:2237-2238. [PubMed: 11044248]

137. Wetzel P, Haag J, Campean V, Goldschmeding R, Atalla A, Amann K, Aigner T. Bone morphogenetic protein-7 expression and activity in the human adult normal kidney is predominantly localized to the distal nephron. Kidney Int. 2006; 70:717-723. [PubMed: 16807538]

138. Almanzar MM, Frazier KS, Dube PH, Piqueras AI, Jones WK, Charette MF, Paredes AL. Osteogenic protein-1 mRNA expression is selectively modulated after acute ischemic renal injury. J Am Soc Nephrol. 1998; 9:1456-1463. [PubMed: 9697668]

139. Simon M, Maresh JG, Harris SE, Hernandez JD, Arar M, Olson MS, Abboud HE. Expression of bone morphogenetic protein-7 mRNA in normal and ischemic adult rat kidney. Am J Physiol. 1999; 276:F382-F389. [PubMed: 10070161]

140. Gould SE, Day M, Jones SS, Dorai H. BMP-7 regulates chemokine, cytokine, and hemodynamic gene expression in proximal tubule cells. Kidney Int. 2002; 61:51-60. [PubMed: 11786084]

141. Hruska KA, Guo G, Wozniak M, Martin D, Miller S, Liapis H, Loveday K, Klahr S, Sampath TK, Morrissey J. Osteogenic protein-1 prevents renal fibrogenesis associated with ureteral obstruction. Am J Physiol Renal Physiol. 2000; 279:F130-F143. [PubMed: 10894795]

142. Vukicevic S, Basic V, Rogic D, Basic N, Shih MS, Shepard A, Jin D, Dattatreyamurty B, Jones W, Dorai H, Ryan S, Griffiths D, Maliakal J, Jelic M, Pastorcic M, Stavljenic A, Sampath TK. Osteogenic protein-1 (bone morphogenetic protein-7) reduces severity of injury after ischemic acute renal failure in rat. J Clin Invest. 1998; 102:202-214. [PubMed: 9649574]

143. Zeisberg M, Bottiglio C, Kumar N, Maeshima Y, Strutz F, Muller GA, Kalluri R. Bone morphogenic protein-7 inhibits progression of chronic renal fibrosis associated with two genetic mouse models. Am J Physiol Renal Physiol. 2003; 285:F1060-F1067. [PubMed: 12915382]

144. Zeisberg M, Muller GA, Kalluri R. Are there endogenous molecules that protect kidneys from injury? The case for bone morphogenic protein-7 (BMP-7). Nephrol Dial Transplant. 2004; 19:759-761. [PubMed: 15031324]

145. Zeisberg M, Hanai J, Sugimoto H, Mammoto T, Charytan D, Strutz F, Kalluri R. BMP-7 counteracts TGF-beta1-induced epithelial-to-mesenchymal transition and reverses chronic renal injury. Nat Med. 2003; 9:964-968. [PubMed: 12808448]

146. Zeisberg M, Shah AA, Kalluri R. Bone morphogenic protein-7 induces mesenchymal to epithelial transition in adult renal fibroblasts and facilitates regeneration of injured kidney. J Biol Chem. 2005; 280:8094-8100. [PubMed: 15591043]

147. Miller RK, McCrea PD. Wnt to build a tube: contributions of Wnt signaling to epithelial tubulogenesis. Dev Dyn. 2010; 239:77-93. [PubMed: 19681164]

148. MacDonald BT, Tamai K, He X. Wnt/beta-catenin signaling: components, mechanisms, and diseases. Dev Cell. 2009; 17:9-26. [PubMed: 19619488]

149. Saulnier DM, Ghanbari H, Brandli AW. Essential function of Wnt-4 for tubulogenesis in the Xenopus pronephric kidney. Dev Biol. 2002; 248:13-28. [PubMed: 12142017]

150. Naylor RW, Jones EA. Notch activates Wnt-4 signalling to control medio-lateral patterning of the pronephros. Development. 2009; 136:3585-3595. [PubMed: 19793883] 
151. Roel G, Gent YY, Peterson-Maduro J, Verbeek FJ, Destree O. Lef1 plays a role in patterning the mesoderm and ectoderm in Xenopus tropicalis. Int J Dev Biol. 2009; 53:81-89. [PubMed: 19123129]

152. Lyons JP, Miller RK, Zhou X, Weidinger G, Deroo T, Denayer T, Park JI, Ji H, Hong JY, Li A, Moon RT, Jones EA, Vleminckx K, Vize PD, McCrea PD. Requirement of Wnt/beta-catenin signaling in pronephric kidney development. Mech Dev. 2009; 126:142-159. [PubMed: 19100832]

153. Carroll TJ, Park JS, Hayashi S, Majumdar A, McMahon AP. Wnt9b plays a central role in the regulation of mesenchymal to epithelial transitions underlying organogenesis of the mammalian urogenital system. Dev Cell. 2005; 9:283-292. [PubMed: 16054034]

154. Majumdar A, Vainio S, Kispert A, McMahon J, McMahon AP. Wnt11 and Ret/Gdnf pathways cooperate in regulating ureteric branching during metanephric kidney development. Development. 2003; 130:3175-3185. [PubMed: 12783789]

155. Stark K, Vainio S, Vassileva G, McMahon AP. Epithelial transformation of metanephric mesenchyme in the developing kidney regulated by Wnt-4. Nature. 1994; 372:679-683. [PubMed: 7990960]

156. Yu J, Carroll TJ, Rajagopal J, Kobayashi A, Ren Q, McMahon AP. A Wnt7b-dependent pathway regulates the orientation of epithelial cell division and establishes the cortico-medullary axis of the mammalian kidney. Development. 2009; 136:161-171. [PubMed: 19060336]

157. Bridgewater D, Cox B, Cain J, Lau A, Athaide V, Gill PS, Kuure S, Sainio K, Rosenblum ND. Canonical WNT/beta-catenin signaling is required for ureteric branching. Dev Biol. 2008; 317:83-94. [PubMed: 18358465]

158. Karner CM, Dietrich MF, Johnson EB, Kappesser N, Tennert C, Percin F, Wollnik B, Carroll TJ, Herz J. Lrp4 regulates initiation of ureteric budding and is crucial for kidney formation--a mouse model for Cenani-Lenz syndrome. PLoS One. 2010; 5:e10418. [PubMed: 20454682]

159. Kuure S, Popsueva A, Jakobson M, Sainio K, Sariola H. Glycogen synthase kinase-3 inactivation and stabilization of beta-catenin induce nephron differentiation in isolated mouse and rat kidney mesenchymes. J Am Soc Nephrol. 2007; 18:1130-1139. [PubMed: 17329570]

160. Nguyen HT, Thomson AA, Kogan BA, Baskin LS, Cunha GR. Expression of the Wnt gene family during late nephrogenesis and complete ureteral obstruction. Lab Invest. 1999; 79:647658. [PubMed: 10378507]

161. Surendran K, McCaul SP, Simon TC. A role for Wnt-4 in renal fibrosis. Am J Physiol Renal Physiol. 2002; 282:F431-F441. [PubMed: 11832423]

162. Dirocco DP, Kobayashi A, Taketo MM, McMahon AP, Humphreys BD. Wnt4/beta-Catenin Signaling in Medullary Kidney Myofibroblasts. J the Am Soc Nephrol. 2013

163. Lin SL, Li B, Rao S, Yeo EJ, Hudson TE, Nowlin BT, Pei H, Chen L, Zheng JJ, Carroll TJ, Pollard JW, McMahon AP, Lang RA, Duffield JS. Macrophage Wnt7b is critical for kidney repair and regeneration. Proc Natl Acad Sci U S A. 2010; 107:4194-4199. [PubMed: 20160075]

164. Kudoh T, Tsang M, Hukriede NA, Chen X, Dedekian M, Clarke CJ, Kiang A, Schultz S, Epstein JA, Toyama R, Dawid IB. A gene expression screen in zebrafish embryogenesis. Genome Res. 2001; 11:1979-1987. [PubMed: 11731487]

165. Thisse B, Heyer V, Lux A, Alunni V, Degrave A, Seiliez I, Kirchner J, Parkhill JP, Thisse C. Spatial and temporal expression of the zebrafish genome by large-scale in situ hybridization screening. Methods Cell Biol. 2004; 77:505-519. [PubMed: 15602929]

166. Tsang M, Friesel R, Kudoh T, Dawid IB. Identification of Sef, a novel modulator of FGF signalling. Nat Cell Biol. 2002; 4:165-169. [PubMed: 11802164]

167. Rosselot C, Spraggon L, Chia I, Batourina E, Riccio P, Lu B, Niederreither K, Dolle P, Duester G, Chambon P, Costantini F, Gilbert T, Molotkov A, Mendelsohn C. Non-cell-autonomous retinoid signaling is crucial for renal development. Development. 2010; 137:283-292. [PubMed: 20040494]

168. Schaier M, Jocks T, Grone HJ, Ritz E, Wagner J. Retinoid agonist isotretinoin ameliorates obstructive renal injury. J Urol. 2003; 170:1398-1402. [PubMed: 14501777]

169. Torban E, Eccles MR, Favor J, Goodyer PR. PAX2 suppresses apoptosis in renal collecting duct cells. Am J Pathol. 2000; 157:833-842. [PubMed: 10980123] 
170. Carroll T, Wallingford J, Seufert D, Vize PD. Molecular regulation of pronephric development. Curr Top Dev Biol. 1999; 44:67-100. [PubMed: 9891877]

171. Pedersen A, Skjong C, Shawlot W. Lim 1 is required for nephric duct extension and ureteric bud morphogenesis. Dev Biol. 2005; 288:571-581. [PubMed: 16216236]

172. Tucker JA, Mintzer KA, Mullins MC. The BMP signaling gradient patterns dorsoventral tissues in a temporally progressive manner along the anteroposterior axis. Dev Cell. 2008; 14:108-119. [PubMed: 18194657] 


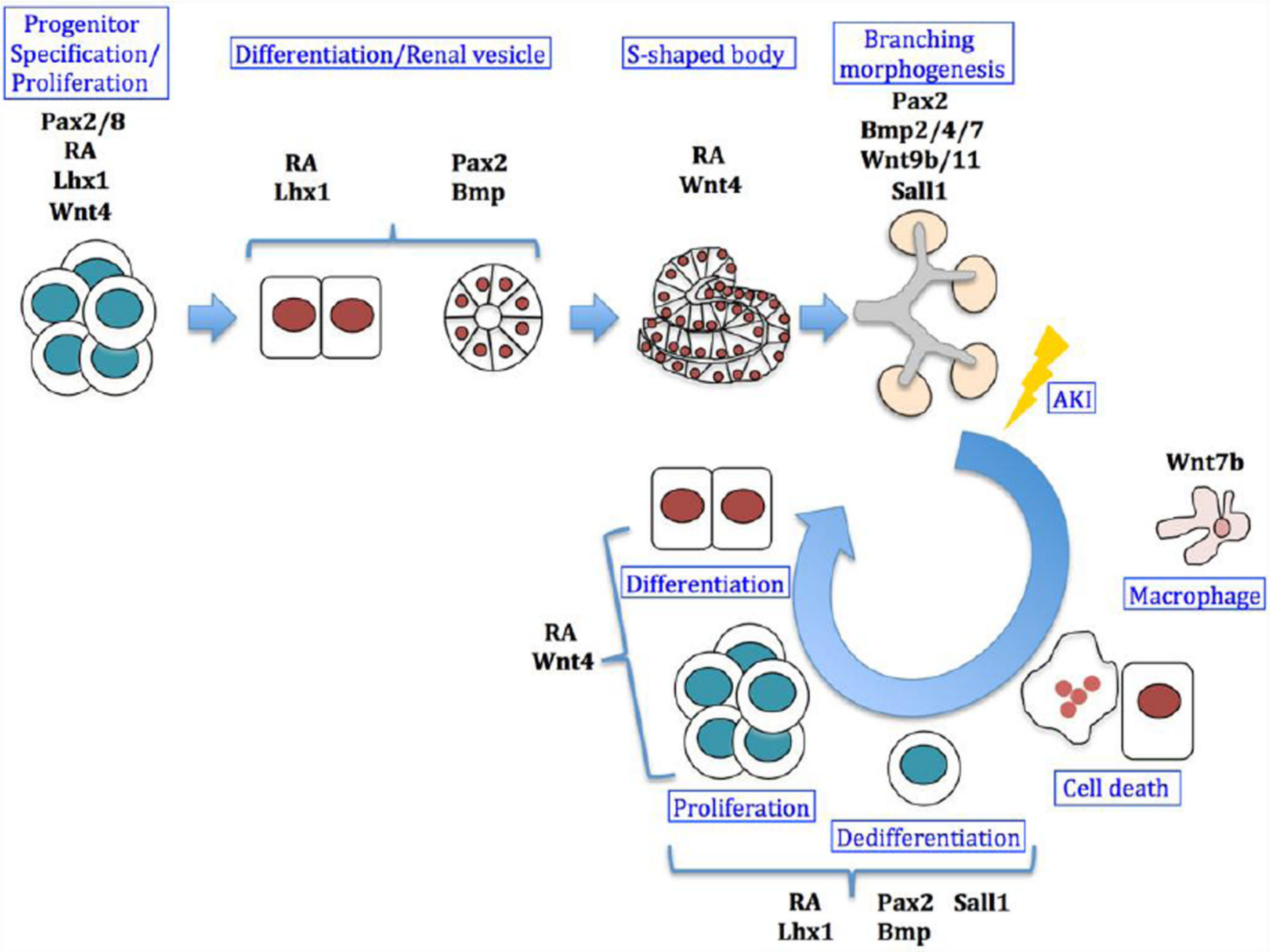

Figure 1. Molecular pathways involved in kidney development and regeneration A simplified scheme of kidney development (top row) and acute kidney injury (AKI) induced regeneration (circle). During development, RA drives renal progenitor cells to undergo specification followed by proliferation events while expressing the early pre-tubular markers Pax 2/8, Lhxl and Wnt4. Later, RA induces expression of Lhxl which has a role in the patterning of the renal vesicles together with Pax2, and Bmp proteins which induce mesenchyme polarization. The formation of the S-shaped bodies coincides with activation of the Wnt pathway, which is essential for the proximo-distal patterning of the nephron together with RA signaling. Branching of the ureteric bud within the metanephric mesenchyme is regulated by Pax 2 and Wnt9b/11 among other factors. Bmp signaling has a role in regulating branching, both positively (Bmp7) and negatively (Bmp4 and Bmp2). Following tubular damage induced by AKI, epithelial cells are lost and the basement membrane is denuded. Wnt7b might act as a pro-survival signal from macrophages that preserves basement membrane integrity. During the regeneration process, the surviving epithelial cells undergo dedifferentiation and reactivation of nephrogenic markers such as Pax2, Bmps, and Lhx1. Proliferation and differentiation of these cells is possibly mediated by RA and Wnt4, providing the source of replacement cells necessary for restoring a functional tubule 
Table 1

Summary of the pathways and genes with roles in kidney development and regeneration following injury.

\begin{tabular}{|c|c|c|c|}
\hline Pathway & Role in development & Role in regeneration & References \\
\hline Retinoids & $\begin{array}{l}\text { Pronephros: specification, tubule morphogenesis, } \\
\text { segmentation of the tubule } \\
\text { Metanephros: branching morphogenesis }\end{array}$ & Pro-survival & $\begin{array}{l}\text { Development: }[53-59,64,65, \\
\text { 167] } \\
\text { Regeneration: }[76,168]\end{array}$ \\
\hline $\begin{array}{l}\text { Pax } \\
(\operatorname{Pax} 2 / \operatorname{Pax} 8)\end{array}$ & $\begin{array}{l}\text { Pronephros: specification of the pronephric lineage } \\
\text { Metanephros: ureteric budding, branching } \\
\text { morphogenesis }\end{array}$ & $\begin{array}{l}\text { Anti-apoptotic } \\
\text { Pro-survival }\end{array}$ & $\begin{array}{l}\text { Development: }[84-86,92] \\
\text { Regeneration: }[95,96,169]\end{array}$ \\
\hline Lhx 1 & $\begin{array}{l}\text { Pronephros: specification of the pronephric lineage } \\
\text { Mesonephros: maintenance of nephric duct and } \\
\text { tubules } \\
\text { Metanephros: formation of ureteric bud and renal } \\
\text { vesicles patterning }\end{array}$ & $\begin{array}{l}\text { Unknown in mammals } \\
\text { Reactivated maker of stem cells } \\
\text { during repair following AKI in adult } \\
\text { zebrafish }\end{array}$ & $\begin{array}{l}\text { Development: }[98,101,170, \\
\text { 171] } \\
\text { Regeneration: }[10,30]\end{array}$ \\
\hline Sall1 & $\begin{array}{l}\text { Expressed in pronephros and mesonephros } \\
\text { Metanephros: uretheric bud branching }\end{array}$ & $\begin{array}{l}\text { Increased expression in mice } \\
\text { following ischemia-reperfusion } \\
\text { injury. } \\
\text { Increased proliferation of Sall1- } \\
\text { positive cells }\end{array}$ & $\begin{array}{l}\text { Development: }[107,109,112, \\
\text { 113] } \\
\text { Regeneration: [114] }\end{array}$ \\
\hline Bmp & $\begin{array}{l}\text { Pronephros: patterning of the intermediate } \\
\text { mesoderm } \\
\text { Metanephros: patterning (Bmp7), regulation of } \\
\text { branching morphogenesis (Bmp2/Bmp4/Bmp7), }\end{array}$ & $\begin{array}{l}\text { Anti-apoptotic, reduction of immune } \\
\text { response, prevention of } \\
\text { tubulointerstitial fibrosis }\end{array}$ & $\begin{array}{l}\text { Development: }[14,116,117, \\
\text { 122-124, 128, 131, 172] } \\
\text { Regeneration: }[140-142,145, \\
146]\end{array}$ \\
\hline Wnt & $\begin{array}{l}\text { Pronephros: patterning of the intermediate } \\
\text { mesoderm, tubulogenesis (Wnt } 4 \text { /Wnt11) } \\
\text { Metanephros: mesenchyme-to-epithelium transition } \\
\text { (Wnt4), tubulogenesis (Wnt4), cortico-medullar } \\
\text { morphogenesis (Wnt7b), branching morphogenesis } \\
\text { (Wnt9b/Wnt11) }\end{array}$ & $\begin{array}{l}\text { Reactivated during repair following } \\
\text { AKI (Wnt } 4 / \text { Wnt } 7 b) \\
\text { Anti-apoptotic (Wnt7b) }\end{array}$ & $\begin{array}{l}\text { Development: }[149,150] \\
{[153-156]} \\
\text { Regeneration: }[47,160,162, \\
163]\end{array}$ \\
\hline
\end{tabular}

